\title{
Channel-levee evolution in combined contour current-turbidity current flows from flume-tank experiments
}

\author{
Elda Miramontes ${ }^{1,2 *}$, Joris T. Eggenhuisen ${ }^{3}$, Ricardo Silva Jacinto², Giovanni Poneti4 ${ }^{4}$ Florian Pohl3,5, \\ Alexandre Normandeau ${ }^{6}$, D. Calvin Campbell ${ }^{6}$ and F. Javier Hernández-Molina ${ }^{7}$ \\ 'Laboratoire Géosciences Océan, UMR 6538, CNRS-Université de Bretagne Occidentale, Institut Universitaire Europeen de la Mer \\ (IUEM), 29280 Plouzané, France \\ 2Géosciences Marines, IFREMER (Institut Français de Recherche pour l'Exploitation de la Mer), 29280 Plouzané, France \\ ${ }^{3}$ Faculty of Geosciences, Utrecht University, 3584 CB Utrecht, Netherlands \\ ${ }^{4}$ Department of Earth Sciences, University of Florence, Florence 50121, Italy \\ ${ }^{5}$ Department of Earth Sciences, Durham University, Durham 1DH 3LE, UK \\ ${ }^{6}$ Geological Survey of Canada (Atlantic), Natural Resources Canada, Dartmouth, Nova Scotia B2Y 4A2, Canada \\ ${ }^{7}$ Department of Earth Sciences, Royal Holloway University of London, Egham, Surrey TW20 OEX, UK
}

\begin{abstract}
Turbidity currents and contour currents are common sedimentary and oceanographic processes in deep-marine settings that affect continental margins worldwide. Their simultaneous interaction can form asymmetric and unidirectionally migrating channels, which can lead to opposite interpretations of paleocontour current direction: channels migrating against the contour current or in the direction of the contour current. In this study, we performed three-dimensional flume-tank experiments of the synchronous interaction between contour currents and turbidity currents to understand the effect of these combined currents on channel architecture and evolution. Our results show that contour currents with a velocity of $10-19 \mathrm{~cm} \mathrm{~s}^{-1}$ can substantially deflect the direction of turbidity currents with a maximum velocity of 76-96 $\mathrm{cm} \mathrm{s}^{-1}$, and modify the channel-levee system architecture. A lateral and nearly stationary front formed on the levee located upstream of the contour current, reduced overspill and thus restrained the development of a levee on this side of the channel. Sediment was preferentially carried out of the channel at the flank located downstream of the contour current. An increase in contour-current velocity resulted in an increase in channel-levee asymmetry, with the development of a wider levee and more abundant bedforms downstream of the contour current. This asymmetric deposition along the channel suggests that the direction of long-term migration of the channel form should go against the direction of the contour current due to levee growth downstream of the contour current, in agreement with one of the previously proposed conceptual models.
\end{abstract}

\section{INTRODUCTION}

Turbidity currents are underwater gravitydriven flows that transport large amounts of sediment to the deep sea (Normark, 1970). They play an important role in global carbon cycling and sequestration (Galy et al., 2007), bring nutrients to deep-sea ecosystems (Khripounoff et al., 2012), transport microplastics downslope (Kane and Clare, 2019), and can pose a hazard for seafloor infrastructure (Carter et al., 2014). More-

*Current address: Faculty of Geosciences and MARUM-Center for Marine Environmental Sciences, University of Bremen, Bremen 28359, Germany; E-mail: emiramon@uni-bremen.de. over, their deposits can host reservoirs for hydrocarbons (Mayall et al., 2006) and can be used as archives for paleoclimatic reconstructions (Bonment from the continent to the deep sea through gravity flows has mainly been considered to be a downslope process, many systems show characteristics that suggest that turbidity currents and their related deposits (i.e., turbidites) can be affected by along-slope bottom currents (i.e., contour currents), resulting in the formation of asymmetric channel-levee systems (Fig. 1). Asymmetrical and unidirectionally migrating submarine channels and canyons have widely been used for paleoceanographic reconstrucneau et al., 2014). Although the transfer of sedi- tions (e.g., He et al., 2013). However, because the processes at the origin of these sedimentary bodies are not well understood, the interpretations of the current directions based on the deposits are disputed in literature. For instance, Fonnesu et al. (2020) suggested that channels migrate in the upstream direction of contour currents due to levee growth on the downstream side of contour currents. In contrast, Gong et al. (2018) suggested that channels migrate in the downstream direction of contour currents, and that levees mainly grow upstream of the contour current. In our study, we recorded the interplay between contour currents and turbidity currents in three-dimensional flume-tank experiments in order to gather first-order observations of how downslope and along-slope processes interact, and how contour currents may affect the geometry of channel-levee systems.

\section{FLUME-TANK EXPERIMENTS}

Experiments that simulated the simultaneous interaction between contour currents and turbidity currents were carried out in the Eurotank Flume Laboratory (Utrecht University, Netherlands), an $11 \times 6 \times 1.2 \mathrm{~m}$ basin, where experiments on channel-levee systems have been successfully performed in previous studies (de Leeuw et al., 2016, 2018a, 2018b). Turbidity currents were generated by pumping a mixture of sediment and water (median grain size of $133 \mu \mathrm{m}$; volume concentration of sediment $17 \%$; volume of $0.9 \mathrm{~m}^{3}$, and discharge of $\sim 30 \mathrm{~m}^{3} \mathrm{hr}^{-1}$ ) into a preformed channel on an $11^{\circ}$ slope. The shape and dimensions of the channel ( $80 \mathrm{~cm}$ wide and $3 \mathrm{~cm}$ deep) were identical to

CITATION: Miramontes, E., et al., 2020, Channel-levee evolution in combined contour current-turbidity current flows from flume-tank experiments: Geology, v. 48 , p. 353-357, https://doi.org/10.1130/G47111.1 


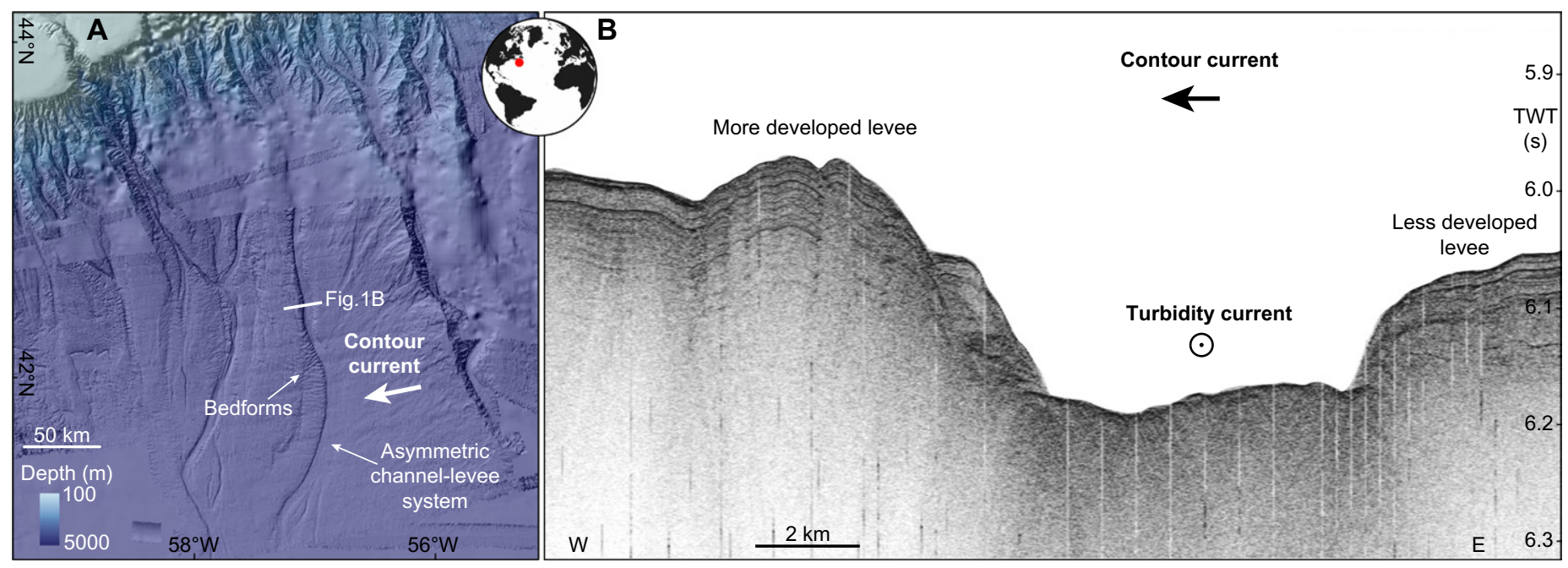

Figure 1. Multibeam bathymetry (A) and $3.5 \mathrm{kHz}$ subbottom profiler image (B) of mixed turbidite-contourite system offshore eastern Canada (location indicated with red dot in inset), characterized by an asymmetric channel-levee system and an asymmetric distribution of bedforms. TWT-two-way traveltime.

those of Leeuw et al.'s (2018b) run 5. This channel form was chosen because a significant part of the turbidity current elevated above the channel flanks during the experiments and would have thus interacted with the contour current. In our study, we implemented an array of pumps that generated water circulation in the basin, and contour currents along the slope (Fig. DR1 in the GSA Data Repository ${ }^{1}$ ). In our first experiment, the turbidity current flowed through standing water without contour currents. Then, three more experiments were carried out maintaining a similar preparation of the turbidity current, but with three different contour-current velocities $\left(10,14\right.$, and $\left.19 \mathrm{~cm} \mathrm{~s}^{-1}\right)$, using, respectively, 1,2 , and 3 pumps (Fig. DR2). The velocity of the contour currents and turbidity currents was measured using a Signal Processing SA (https:// www.signal-processing.com) UDOP 4000 velocimeter, which was located in the middle of the slope in the channel thalweg. This velocimeter measured time series of velocity profiles of the across- and along-slope velocity component (Figs. DR1 and DR3).

\section{MODIFICATION OF TURBIDITY CURRENT STRUCTURE BY CONTOUR CURRENTS}

The turbidity current flowing in standing water overspilled symmetrically over both flanks of the channel (Fig. 2A). In contrast, overspilling was asymmetric in the presence of a contour current. Underwater images of the experiment clearly show that overspill occurred mainly downstream of the contour current (Fig. 2B).

${ }^{1}$ GSA Data Repository item 2020094, additional details on the experimental setup and underwater video of the experiments, is available online at http:// www.geosociety.org/datarepository/2020/, or on request from editing@geosociety.org.
Upstream of the contour current, overspill of the turbidity current was blocked by the opposing contour current, generating a stationary lateral front (Fig. 2). Part of the sediment carried by the turbidity current was advected by the contour current and transported in suspension along slope (Fig. 2B).

The contour currents substantially modified the flow properties of turbidity currents, especially the time-averaged downslope velocity and the direction of the flow (Fig. 3). In the experiment with the turbidity current in standing water, the time-averaged downslope velocity maximum was $87 \mathrm{~cm} \mathrm{~s}^{-1}$. In the experiments with contour currents of 10 and $14 \mathrm{~cm} \mathrm{~s}^{-1}$, the velocity maximum increased to $96 \mathrm{~cm} \mathrm{~s}^{-1}$, whereas with the strongest contour current $\left(19 \mathrm{~cm} \mathrm{~s}^{-1}\right)$, it decreased to $76 \mathrm{~cm} \mathrm{~s}^{-1}$. The ratio of contourcurrent speed and maximum downslope turbidity-current velocity thus increased from 0.10 to

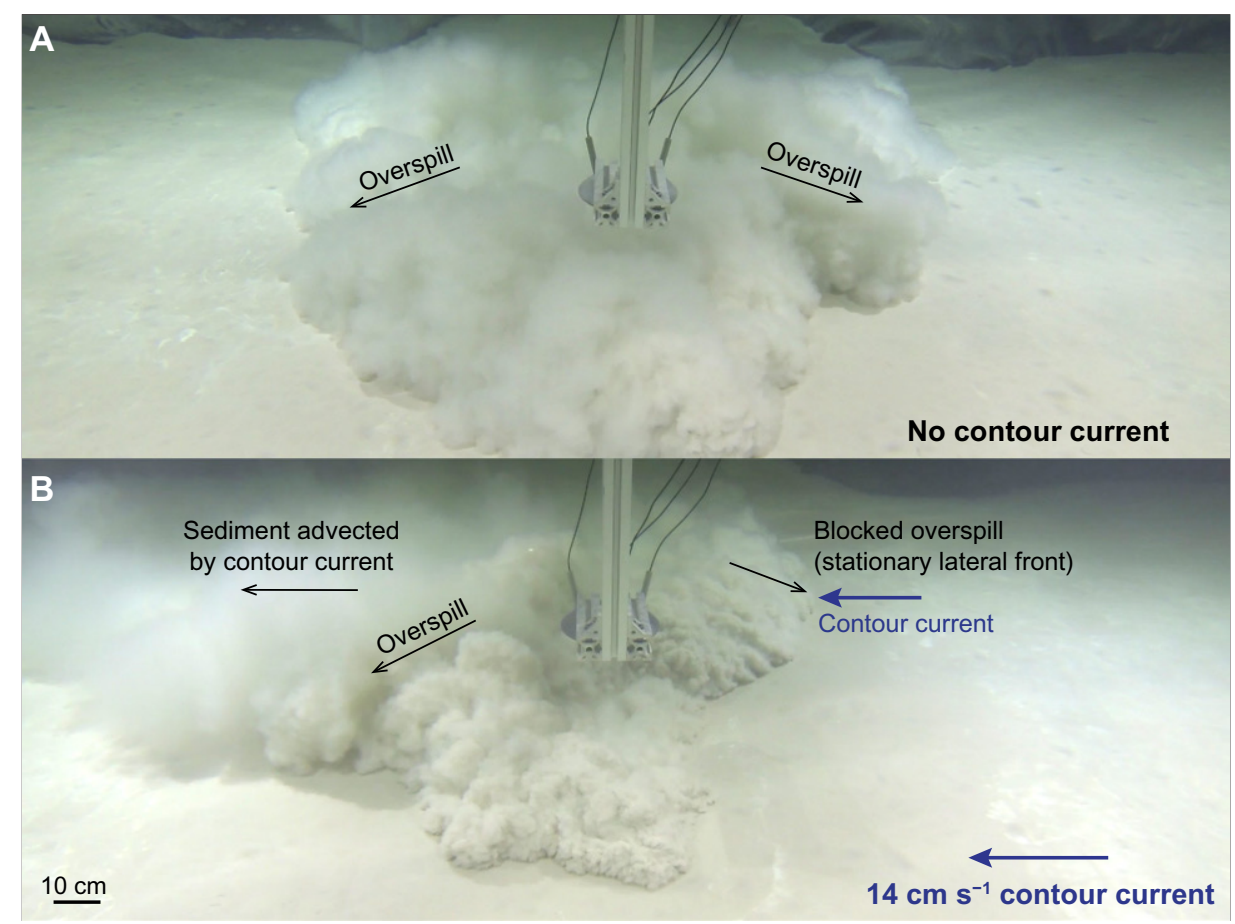

Figure 2. Single frames from video of a turbidity current during two experiments: a turbidity current flowing in standing water without a contour current $(A)$; and a turbidity current interacting with a contour current of $14 \mathrm{~cm} \mathrm{~s}^{-1}(B)$. The UDOP 4000 velocimeter, used to measure velocity profiles during experiments, can be observed in the center of the images. Full video is available in the Data Repository (see footnote 1 ). 

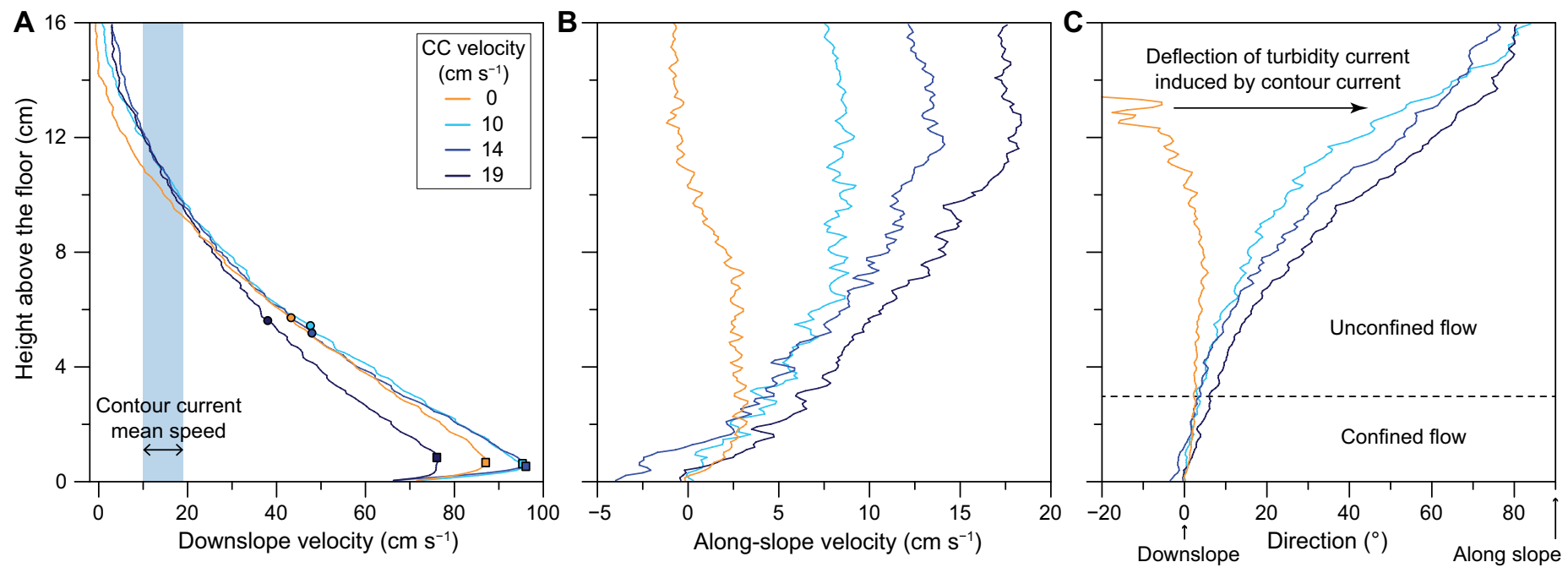

Figure 3. (A) Time-averaged downslope velocity profile for all experiments. Squares represent maximum velocity of turbidity currents, and circles represent flow thickness, which is here defined as the height at which the velocity is half the velocity maximum. Vertical light-blue band indicates the range of mean contour current speed used in the experiments $\left(10-19 \mathrm{~cm} \mathrm{~s}^{-1}\right)$. (B) Time-averaged, along-slope velocity profile for all experiments. (C) Time-averaged direction of turbidity current for each experiment. CC-contour current.

0.15 and to 0.25 in the three contour current experiments. The mean flow thickness, here calculated as the height at which the velocity is half the velocity maximum, was similar in all the experiments, ranging between 5.2 and $5.7 \mathrm{~cm}$ (Fig. 3A). The along-slope velocity component of the turbidity current in standing water was $2.5 \mathrm{~cm} \mathrm{~s}^{-1}$, which is a small fraction of the downslope velocity component $\left(87 \mathrm{~cm} \mathrm{~s}^{-1}\right)$.

With introduction of a contour current, the along-slope velocity component of the turbidity current increased with the velocity of the contour current (Fig. 3B). The current profile resulting from the combination of the contour current and the turbidity current had a spiral structure; i.e., the direction of the flow changed with the distance from the floor, turning progressively along slope (downstream of the contour current). This change in direction was especially obvious above $3 \mathrm{~cm}$, where the flow was unconfined above the channel (Fig. 3C).

\section{DEVELOPMENT OF AN ASYMMETRIC CHANNEL-LEVEE SYSTEM}

The changes in the properties of turbidity currents induced by the simultaneous interaction with contour currents are reflected in the resulting deposits (Fig. 4). Deposition maps were obtained from differential topographies measured with a laser scanner before and after the experiments (Fig. DR1). In the experiment in standing water, symmetric levees with bedforms (ripples at this scale) formed on both sides of the channel, with their crests oriented at an angle of $30^{\circ}-45^{\circ}$ with respect to the channel (Fig. 4A). In contrast, levees became more asymmetric with increasing contour-current velocity, due to an enhancement in sediment accumulation on the levee downstream of the contour current. Upstream of the contour current, the levee became narrower and bedforms progressively disappeared, whereas downstream of the contour current, the levees became wider and the bedforms formed over a larger area (Fig. 4). The effect of the contour currents was especially marked in the levee width (Fig. DR4F). The faster the contour current flowed, the narrower the levee was upstream of the contour current, and the wider it was downstream of the contour current. However, the effect of the contour currents was less marked in the levee height, which may have been controlled by other secondary processes and not directly by the contour currents (Fig. 4; Fig. DR4E).

The asymmetry observed in the deposits agrees with velocity measurements and observations in underwater videos, which showed a deviation of the entire turbidity current in the direction of the contour current. Changes in deposition thickness within the channel and in the position of the lobes are also observed in the experiments. With weak contour currents $(10 \mathrm{~cm}$ $\mathrm{s}^{-1}$ ), less sediment accumulated within the channel, and the lobe was located farther downslope compared to the experiment in standing water. High contour-current velocities resulted in a progressive enhancement of the channel infill and a reduction of the runout distance (Fig. 4).

\section{DISCUSSION AND CONCLUSION}

Comparison with Natural Mixed TurbiditeContourite Systems

Turbidity currents are energetic flows with velocities ranging from few decimeters to a few meters per second (e.g., Azpiroz-Zabala et al., 2017). The velocities of contour currents along continental margins, however, are typically in a narrower range, of few tens of centimeters per second (Shanmugam et al., 1993). We consider the ratio between along- slope contour-current velocity and the maximum downslope velocity of turbidity currents as the best scaling ratio for the relative strength of contour currents and turbidity currents. In our experiments, the velocity of the contour current was between $10 \%$ and $25 \%$ of the maximum velocity of the turbidity current. The modest interactions observed in the experiment with a $10 \mathrm{~cm} \mathrm{~s}^{-1}$ contour current could thus scale to natural contour currents of $0.2 \mathrm{~m} \mathrm{~s}^{-1}$ and turbidity currents of $2 \mathrm{~m} \mathrm{~s}^{-1}$, or to weaker contour currents and slower turbidity currents. The strong interaction observed in the experiment with a $19 \mathrm{~cm} \mathrm{~s}^{-1}$ contour current could scale to the effect of a $0.2 \mathrm{~m} \mathrm{~s}^{-1}$ contour current on a turbidity current traveling at $<1 \mathrm{~m}$ $\mathrm{s}^{-1}$, or alternatively to a stronger contour current affecting a faster turbidity current. These projected ranges of scaled turbidity-current velocities illustrate that the interactions observed in this study can be expected to occur for the full range of recorded turbidity-current velocities (Khripounoff et al., 2012; Hughes Clarke et al., 2016; Azpiroz-Zabala et al., 2017), with the exception of highly energetic turbidity currents in steep proximal canyons (Paull et al., 2018).

The channel-levee architecture resulting from the simultaneous interaction of turbidity currents with contour currents in our experiments is similar to that of natural mixed turbidite-contourite systems, with a more developed levee, and more abundant bedforms, downstream of the contour currents (Fig. 1; Normandeau et al., 2019; Fonnesu et al., 2020). We conclude that sedimentation is enhanced in the levee located downstream of the contour current, probably resulting in a channel migrating upstream of the contour current, as suggested for mixed systems in northern Mozambique (Fonnesu et al., 2020) and in Nova 

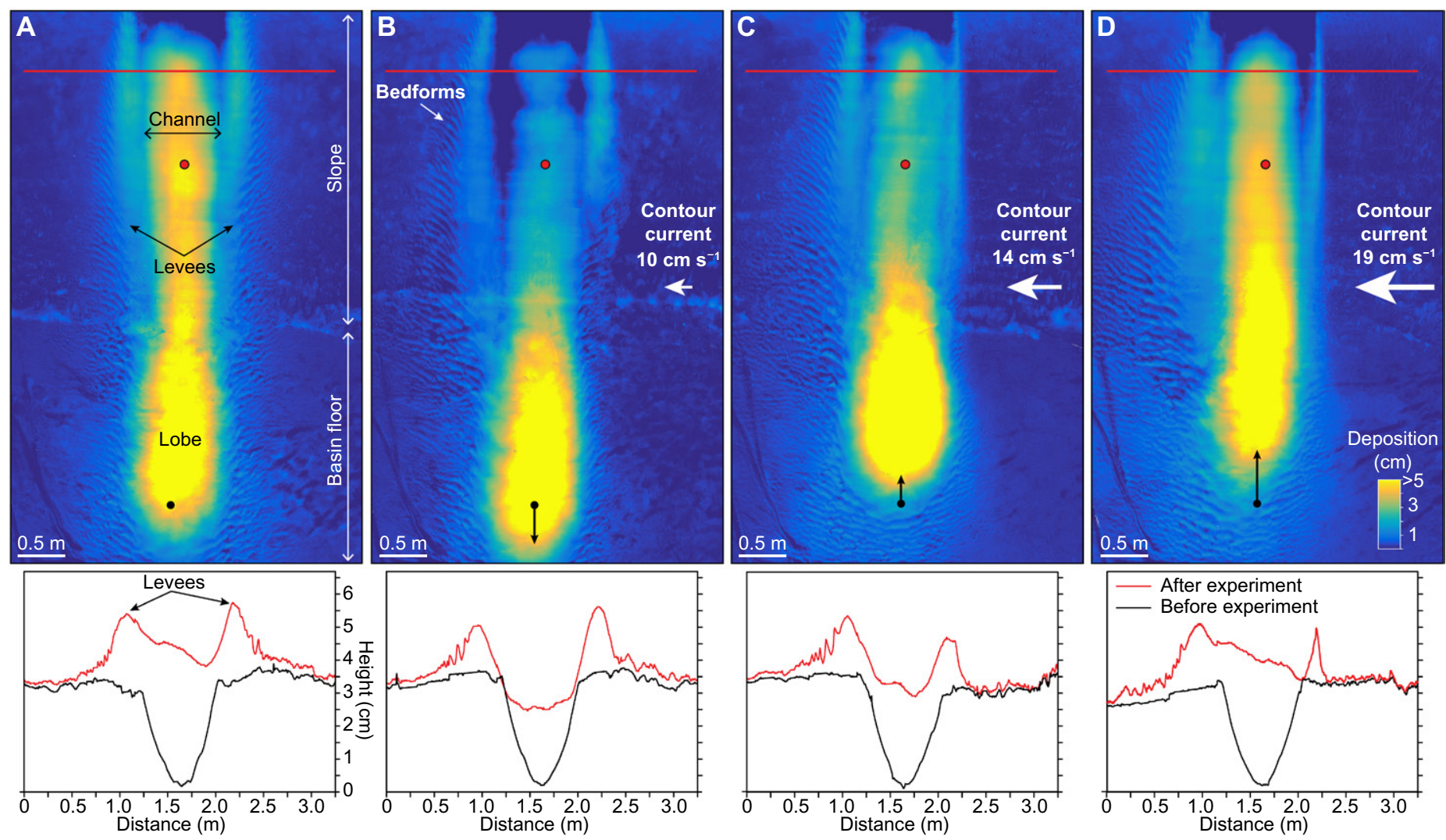

Figure 4. Deposition maps and cross sections during experiments of turbidity currents with no contour current interaction (A), and with interaction with contour currents of $10 \mathrm{~cm} \mathrm{~s}^{-1}(B), 14 \mathrm{~cm} \mathrm{~s}^{-1}(C)$, and $19 \mathrm{~cm} \mathrm{~s}^{-1}$ (D). Red lines represent location of cross sections. Red dot represents the point of current velocity measurements. Black dots and black arrows represent how the frontal part of the deposit with sediment deposition $>5 \mathrm{~cm}$ was displaced compared to the experiment in standing water. In the cross sections, black and red lines indicate the profile before and after the experiment, respectively.

Scotia, Canada (Campbell and Mosher, 2016), and not migrating downstream of the contour current as suggested for the South China Sea (He et al., 2013) and the Congo Basin, central Africa (Gong et al., 2018).

In our experiments, we observed flow instabilities at the lateral front that propagated along slope in the direction of the contour currents (Fig. 2B). Gong et al. (2018) suggested that Kelvin-Helmholtz billows and bores, formed in the pycnocline between turbidity and contour currents, could generate erosion on the channel flank located downstream of the contour current, and deposition upstream of the contour current. However, in our study, we observed the opposite pattern, and we conclude that billows and bores moving along slope on the top of the turbidity current did not play a crucial role in the generation of asymmetric channel-levee systems in these experiments. The asymmetry could be simply explained by the deviation of turbidity currents and by asymmetric overspill. The lateral front is important in blocking overspill and generating linear narrow levees when turbidity currents interact with strong contour currents (Fig. 4D), in agreement with the conceptual model suggested by Fonnesu et al. (2020) for the mixed turbidite-contourite system off northern Mozambique.

\section{Combined Flows in Synchronous Mixed Systems}

In our experiments, the velocity of most of the turbidity currents was higher than the velocity of the contour currents (Fig. 3A). The speed of the contour current and that of the turbidity current in standing water was equal at $9-11 \mathrm{~cm}$ above the flume floor (Fig. 3A), but the change in direction of the turbidity current was already observed $3 \mathrm{~cm}$ above the bed, where the turbiditycurrent velocity was $>3 \times$ higher than the contourcurrent velocity (Fig. 3C). From this elevation upward, the direction of the velocity changed in a helical fashion until it was directed perpendicular to the downslope velocity at the base of the flow. Furthermore, the maximum downslope velocity within the channel as well as the travel distance of sediment onto the basin floor seemed affected by the contour-current strength (Figs. 3A and 4). But perhaps most importantly, the contour current greatly impacted the cross-sectional flow structure of the channelized turbidity current. This can be explained by the contour-current velocities of $10-19 \mathrm{~cm} \mathrm{~s}^{-1}$ being an order of magnitude higher than the along-slope velocity components of the turbidity current in standing water (Fig. 3B). The resulting combined-flow structure displayed characteristics that belong to neither turbidity current nor contour current, but a combination of both processes that represents a newly described marine environmental flow type. This combined-flow structure dominated the cross-sectional evolution of the channel-levee system. In conclusion, combined flow resulting from synchronous oceanic circulation and turbidity currents should be considered in the analysis of submarine channel systems on continental slopes, especially in zones of the slopes where turbidity currents are traveling down the slope at velocities of $2 \mathrm{~m} \mathrm{~s}^{-1}$ or less, and where submarine channels are not deeply incised, favoring overspill and the interaction between turbidity currents and contour currents.

\section{ACKNOWLEDGMENTS}

Miramontes' postdoctoral fellowship was co-funded by TOTAL (Paris, France) and IFREMER (Institut Français de Recherche pour l'Exploitation de la Mer) as part of the PAMELA (Passive Margin Exploration Laboratories) scientific project. The PAMELA project is a scientific project led by IFREMER and TOTAL in collaboration with Université de Bretagne Occidentale, Université Rennes 1, Université Pierre and Marie Curie, CNRS, and IFPEN (IFP Énergies Nouvelles). This research was funded by the Joint Industry Project (JIP) associated with "The Drifters Research Group" of the Royal Holloway University of London (UK), and it is related to the projects CTM 2012-39599-C03, CGL2016-80445-R, and CTM2016-75129-C3-1-R. Han de Witte provided essential technical assistance to the experiments. Mike Tilston is acknowledged 
for sharing his experience with the UDOP 4000 velocimetry equipment. The contribution by Joris Eggenhuisen was made possible through an NWO (Dutch Research Council) fellowship (grant NWOALW-VIDI 864.13.006). We thank Jaco H. Baas, Marco Fonnesu, and Matthieu Cartigny for their constructive comments, which significantly improved the manuscript.

\section{REFERENCES CITED}

Azpiroz-Zabala, M., Cartigny, M.J.B., Talling, P.J., Parsons, D.R., Sumner, E.J., Clare, M.A., Simmons, S.M., Cooper, C., and Pope, E.L., 2017, Newly recognized turbidity current structure can explain prolonged flushing of submarine canyons: Science Advances, v. 3, e1700200, https://doi .org/10.1126/sciadv. 1700200 .

Bonneau, L., Jorry, S.J., Toucanne, S., Silva Jacinto, R., and Emmanuel, L., 2014, Millennial-scale response of a western Mediterranean river to late Quaternary climate changes: A view from the deep sea: The Journal of Geology, v. 122 . p. 687-703, https://doi.org/10.1086/677844.

Campbell, D.C., and Mosher, D.C., 2016, Geophysical evidence for widespread Cenozoic bottom current activity from the continental margin of Nova Scotia, Canada: Marine Geology, v. 378, p. 237-260, https://doi.org/10.1016/j.margeo.2015.10.005.

Carter, L., Gavey, R., Talling, P.J., and Liu, J.T., 2014, Insights into submarine geohazards from breaks in subsea telecommunication cables: Oceanography (Washington, D.C.), v. 27, p. 58-67, https:// doi.org/10.5670/oceanog.2014.40.

de Leeuw, J., Eggenhuisen, J.T., and Cartigny, M.J.B., 2016, Morphodynamics of submarine channel inception revealed by new experimental approach: Nature Communications, v. 7, 10886, https://doi .org/10.1038/ncomms 10886 .

de Leeuw, J., Eggenhuisen, J.T., and Cartigny, M.J.B., 2018a, Linking submarine channel-levee facies and architecture to flow structure of turbidity currents: Insights from flume tank experiments: Sedimentology, v. 65, p. 931-951, https://do .org/10.1111/sed.12411.

de Leeuw, J., Eggenhuisen, J.T., Spychala, Y.T., Heijnen, M.S., Pohl, F., and Cartigny, M.J.B., 2018b, Sediment volume and grain-size partitioning between submarine channel - levee systems and lobes: An experimental study: Journal of Sedimentary Research, v. 88, p. 777-794, https://doi .org/10.2110/jsr.2018.46.

Fonnesu, M., Palermo, D., Galbiati, M., Marchesini, M., Bonamini, E., and Bendias, D., 2020, A new world-class deep-water play-type, deposited by the syndepositional interaction of turbidity flows and bottom currents: The giant Eocene Coral Field in northern Mozambique: Marine and Petroleum Geology, v. 111, p. 179-201, https://doi .org/10.1016/j.marpetgeo.2019.07.047.

Galy, V., France-Lanord, C., Beyssac, O., Faure, P., Kudrass, H., and Palhol, F., 2007, Efficient organic carbon burial in the Bengal fan sustained by the Himalayan erosional system: Nature, v. 450 , p. $407-410$, https://doi.org/10.1038/ nature 06273 .

Gong, C., Wang, Y., Rebesco, M., Salon, S., and Steel, R.J., 2018, How do turbidity flows interact with contour currents in unidirectionally migrating deep-water channels?: Geology, v. 46, p. 551-554, https://doi.org/10.1130/ G40204.1.

He, Y., Xie, X., Kneller, B.C., Wang, Z., and Li, X., 2013, Architecture and controlling factors of canyon fills on the shelf margin in the Qiongdongnan Basin, northern South China Sea: Marine and Petroleum Geology, v. 41, p. 264-276, https://doi .org/10.1016/j.marpetgeo.2012.03.002.

Hughes Clarke, J.E.H., 2016, First wide-angle view of channelized turbidity currents links migrating cyclic steps to flow characteristics: Nature Communications, v. 7, 11896, https://doi.org/10.1038/ ncomms 11896 .
Kane, I.A., and Clare, M.A., 2019, Dispersion, accumulation, and the ultimate fate of microplastics in deep-marine environments: A review and future directions: Frontiers of Earth Science, v. 7, 80, https://doi.org/10.3389/feart.2019.00080.

Khripounoff, A., Crassous, P., Lo Bue, N., Dennielou, B., and Silva Jacinto, R., 2012, Different types of sediment gravity flows detected in the Var submarine canyon (northwestern Mediterranean Sea): Progress in Oceanography, v. 106, p. 138-153, https://doi.org/10.1016/j.pocean.2012.09.001.

Mayall, M., Jones, E., and Casey, M., 2006, Turbidite channel reservoirs-Key elements in facies prediction and effective development: Marine and Petroleum Geology, v. 23, p. 821-841, https://doi .org/10.1016/j.marpetgeo.2006.08.001.

Normandeau, A., Campbell, D.C., and Cartigny, M.J.B., 2019, The influence of turbidity currents and contour currents on the distribution of deepwater sediment waves offshore eastern Canada: Sedimentology, v. 66, p. 1746-1767, https://doi .org/10.1111/sed.12557.

Normark, W.R., 1970, Growth patterns of deep-sea fans: American Association of Petroleum Geologists Bulletin, v. 54, p. 2170-2195, https:// doi.org/10.1306/5D25CC79-16C1-11D7$8645000102 \mathrm{C} 1865 \mathrm{D}$.

Paull, C.K., et al., 2018, Powerful turbidity currents driven by dense basal layers: Nature Communications, v. 9, 4114, https://doi.org/10.1038/s41467018-06254-6.

Shanmugam, G., Spalding, T.D., and Rofheart, D.H., 1993, Process sedimentology and reservoir quality of deep-marine bottom-current reworked sands (sandy contourites): An example from the Gulf of Mexico: American Association of Petroleum Geologists Bulletin, v. 77, p. 1241-1259, https://doi.org/10.1306/BDFF8E52-1718-11D7$8645000102 \mathrm{C} 1865 \mathrm{D}$

Printed in USA 